\title{
Occupational exposures and chronic airflow limitation
}

\author{
HELEN DIMICH-WARD PhD, SUSAN M KENNEDY PhD, MOIRA CHAN-YEUNG MB FRCPC \\ Environmental and Occupational Lung Diseases Research Unit, Respiratory Division, \\ Department of Medicine, Occupational Hygiene Program, University of British Columbia, \\ Vancouver, British Columbia
}

H Dimich-WaRd, SM Kennedy, M Chan-Yeung. Occupational exposures and chronic airflow limitation. Can Respir J 1996;3(2):133-140.

The recent literature was reviewed to evaluate whether chronic airflow limitation is associated with occupational exposures to dusts. Only those studies that controlled for the effects of smoking were included. There is compelling evidence that exposure to inorganic dusts, such as from coal and hardrock mining or asbestos, are associated with the development of chronic airflow limitation, independently of pneumoconiosis. Nonsmoking gold miners are particularly at high risk of airflow obstruction and emphysema. Findings from studies of organic dusts, such as exposures to wood, cotton, grain or other agricultural dusts, or to mixed dust exposures, were less consistent but tended to show positive dose-response associations. In the majority of studies, no statistical interaction was shown between dust exposures and smoking; however, the effects of the dust exposures were often more pronounced. An occupational history should be considered, in addition to a smoking history, as an integral part of an investigation of chronic airflow limitation in a patient.

Key Words: Chronic airflow limitation, FEV , Occupational exposures, Smoking

Q tudies have shown that the diseases of dusty occupations, $\checkmark$ in particular the pneumoconioses, are on the decline in developed countries. In contrast, mortality rates due to the chronic nonmalignant lung diseases including those charac-

\section{Les expositions professionnelles et l'obstruc- tion respiratoire chronique}

RÉSUMÉ : On a passé en revue les études récentes pour évaluer si l'obstruction respiratoire chronique a un rapport avec les expositions professionnelles aux poussières. Seules les études avec groupe témoin pour les effets du tabagisme ont été retenues. On peut conclure que les expositions aux poussières inorganiques comme celles provenant du charbon et des roches ou de l'amiante est associée à l'obstruction respiratoire chronique, indépendamment d'une pneumoconiose. Les nonfumeurs qui travaillent dans les mines d'or sont particulièrement exposés au développement d'une obstruction respiratoire et d'un emphysème. Les résultats des études sur les poussières organiques, telles que les expositions aux poussières de bois, de coton, de grain ou d'autres poussières agricoles, ou les expositions à plusieurs types de poussières étaient moins constants mais tendaient à démontrer une association dose-réponse positive. Dans la plupart des études, aucun lien statistique n'a été démontré entre les expositions aux poussières et le tabagisme; toutefois, les effets des expositions aux poussières étaient souvent plus prononcés. Par conséquent, les antécédents professionnels tout comme les antécédents de consommation de tabac devraient faire partie intégrante de l'anamnèse chez un patient présentant une obstruction respiratoire chronique.

Correspondence: Dr Helen Dimich-Ward, UBC Department of Medicine, Respiratory Division, Vancouver Hospital and Health Sciences Centre, 2775 Heather Street, Vancouver, British Columbia V5Z 3J5. Telephone 604-875-5548, fax 604-875-4695, e-mail hward@unix.ubc.ca 
dust may cause asthma and asthma-like disorders. On the other hand, it has not been clearly established whether occupational exposures to either organic or inorganic dusts can lead to chronic airflow limitation. Adding to the complexity of this association is the relative contribution of cigarette smoking, a known determinant of respiratory disease.

Most of the available epidemiological studies have been cross-sectional in design. Although these studies are prone to selection biases, any chronic disease risk shown would be underestimated, in the case where large numbers of affected workers have already quit the industry. The ideal prospective study would follow a cohort of workers from first hiring until death, charting the development of illness in every worker. As time and resources prohibit such a study one must rely on shorter periods of follow-up, and on health measurements that predict rather than document morbidity. The most widely accepted predictor of the eventual development of chronic airflow limitation is an accelerated decline in forced expiratory volume in $1 \mathrm{~s}\left(\mathrm{FEV}_{1}\right)(2)$. Not only are the longitudinal decline estimates very much dependant upon the age distribution of the population sample, but the estimates of their variance, and therefore of their significance, are vulnerable to the method of analysis (3). Within-study comparisons of exposure groups, whether derived through cross-sectional or longitudinal designs, are relevant provided that differential selection factors are not present and the known confounders of age and smoking are taken into account in the design or analysis.

This review addresses the question, 'can the exposures that workers have encountered in the course of their daily work lead to chronic airflow limitation?' Three types of exposures are reviewed:

- Inorganic dusts: coal, hard rock and asbestos;

- Organic dusts: cotton, grain, wood and agricultural dusts;

- Mixed dusts: including exposure to fumes and gases.

Studies that were selected for review all had taken into account the contribution of cigarette smoking to the development of chronic airflow limitation by using one of three strategies: analyzing outcomes for nonsmokers separately; using statistical adjustments for smoking status; or matching according to smoking status. Where relevant, Canadian studies were cited preferentially, as were the more recently published studies concerning the chronic respiratory effects of occupational and environmental exposures. It is recognized that occupational exposures are seldom specific, but to a greater or lesser degree are mixed, either due to concurrent exposures, or as a result of the varying work histories of the subjects (4). For the last category, a dominant exposure has not been identified. Types of dusts have been chosen that have been sufficiently studied to evaluate causality, as defined by Hill's (5) criteria of consistency (demonstrated in most populations at risk); strength of association; dose-response relationship; specificity; coherence of the evidence; and biological plausibility.

\section{INORGANIC DUSTS}

Inorganic dust exposure has traditionally been associated with pneumoconiotic changes in the lung parenchyma. However, there has been increasing evidence of associations between inorganic dust exposure and chronic airflow obstruction. For some occupations, eg, coal mining and certain hard rock mining, the evidence is now sufficiently strong for causality to be inferred.

In 1973, Higgins (6) reviewed the published studies of chronic pulmonary disease of men engaged in dusty industries. The majority of studies were cross-sectional in design, comparing dust-exposed and nonexposed workers. In almost all, there were higher prevalence rates of bronchitis and lower ventilatory function in workers exposed to the inorganic dusts, even with adjustment for differences in smoking.

The results of studies published betweeen 1973 and 1985 on coal miners, hardrock miners and quarry workers were reviewed by Becklake (7). Most of the cross-sectional studies showed a higher prevalence of bronchitis and lower mean ventilatory function in exposed compared with nonexposed or less exposed workers. As could be expected, smokers consistently had higher rates of bronchitis and lower average ventilatory function compared with nonsmokers. However, the effects of exposure on the nonsmokers were not evaluated. Longitudinal studies also showed comparable dust and smoking effects on longitudinal decline in $\mathrm{FEV}_{1}$.

Results of cross-sectional and longitudinal studies (8-12) in which the effects of coal mining dust are considered separately from the effects of smoking are shown in Table 1. Significant airflow obstruction was typically found in 6 to $10 \%$ of nonsmoking miners, and a significant dose-response relationship was often shown between cumulative dust exposure and $\mathrm{FEV}_{1}$ or $\mathrm{FEV}_{1}$ /forced vital capacity (FVC)\%. In 1993, Oxman and associates (13) conducted an overview of studies published between 1966 and 1991, concerning the relationship between quantitative estimates of inorganic dust exposure and chronic obstructive lung disease. They concluded that after roughly 35 years of work at a mean coal dust exposure level of $2 \mathrm{mg} / \mathrm{m}^{3}$, approximately $8 \%$ of nonsmoking coal miners (and $6.6 \%$ of smoking miners) could be expected to experience a level of $\mathrm{FEV}_{1}$ less than $80 \%$ of predicted, and $1.2 \%$ of nonsmoking coal miners (and $2.3 \%$ of smoking miners) would have an $\mathrm{FEV}_{1}$ level of less than $65 \%$ predicted. A longitudinal study of American coal miners employed since 1970, when dust exposure levels had been relatively low (12), also showed a significant decrease in both $\mathrm{FEV}_{1}$ and $\mathrm{FEV}_{1} / \mathrm{FVC}$ in relation to dust levels, with an estimated decline in $\mathrm{FEV}_{1}$ of $5.7 \mathrm{~mL}$ for each $\mathrm{mg} / \mathrm{m}^{3}$ year of exposure over their working life.

Studies of gold miners (14-15) suggest an even stronger relationship between dust exposure level and airflow obstruction in hardrock mining compared with coal mining. In the re-analysis by Hnizdo and colleagues (14) of results from a South Africa gold mining cohort the estimated effects of cumulative dust exposure from this mining environment on airflow obstruction was about 10 times greater than that seen in the coal mining cohorts. These effects were even more 
TABLE 1

Fibrogenic inorganic dusts: Relationship between exposure and airflow limitation in studies controlling for the effects of smoking

\begin{tabular}{|c|c|c|c|}
\hline Reference & Population & Exposure measure & Relationship between exposure and outcome \\
\hline 8 & $\begin{array}{l}\text { British coal miners } \\
\mathrm{n}=1677\end{array}$ & $\begin{array}{l}\text { Cumulative dust over } 11 \\
\text { years }\end{array}$ & Significant decline in $\mathrm{FEV}_{1}$ with increased dust exposure \\
\hline 9 & $\begin{array}{l}\text { US surface coal miners } \\
\mathrm{n}=1171\end{array}$ & Duration of work (years) & $\begin{array}{l}\text { No association between years as a surface miner with } \mathrm{FEV}_{1} \\
\text { No interaction of exposure and smoking }\end{array}$ \\
\hline 10 & $\begin{array}{l}\text { British coal miners } \\
\mathrm{n}=3380\end{array}$ & $\begin{array}{l}\text { Cumulative dust over } 10 \\
\text { years }\end{array}$ & $\begin{array}{l}\text { Significant dose-response between dust and airflow limitation in } \\
\text { smokers and nonsmokers. No smoking-exposure interaction }\end{array}$ \\
\hline 11 & $\begin{array}{l}\text { US coal miners } \\
n=1470\end{array}$ & $\begin{array}{l}\text { Underground vs } \\
\text { face workers }\end{array}$ & $\begin{array}{l}\text { Significant } F E V_{1} \text { decline (smoker adjusted) for face workers } \\
\text { Average ratio of } 1.5 \text { for smoking vs exposure effects }\end{array}$ \\
\hline 12 & $\begin{array}{l}\text { US coal miners first } \\
\text { employed after } 1970 \\
n=1885\end{array}$ & Cumulative dust & $\begin{array}{l}\text { Significant dose-response between dust and } \mathrm{FEV}_{1} \text {, adjusted for } \\
\text { smoking } \\
\text { FEV } 1 \text { decline greater in first } 5 \text { years of employment }\end{array}$ \\
\hline 14 & $\begin{array}{l}\text { South African gold miners } \\
n=2209\end{array}$ & Cumulative dust & $\begin{array}{l}\text { Significant dose-response between dust and } \mathrm{FEV}_{1} \text {, similar in } \\
\text { smoking categories } \\
\text { No smoking-exposure interaction in total group }\end{array}$ \\
\hline 15 & $\begin{array}{l}\text { Australian gold miners } \\
n=1093\end{array}$ & $\begin{array}{l}\text { Duration of underground gold } \\
\text { mining }\end{array}$ & $\begin{array}{l}\text { Significant dose-response between duration and obstruction } \\
\text { measures }\end{array}$ \\
\hline 21 & $\begin{array}{l}\text { Canadian nonsmoking } \\
\text { chrysotile miners }\end{array}$ & $\begin{array}{l}\text { Asbestos miners vs } \\
\text { non-exposed manual } \\
\text { workers }\end{array}$ & $\begin{array}{l}\text { Decreased upstream resistance at low volume in miners with } \\
\text { increasing severity as extent of alveolitis and asbestosis } \\
\text { increases }\end{array}$ \\
\hline 22 & $\begin{array}{l}\text { US asbestos insulators } \\
\mathrm{n}=416\end{array}$ & $\begin{array}{l}\text { Insulators vs } \\
\text { reference population }\end{array}$ & $\begin{array}{l}\text { Significantly decreased } \mathrm{FEV}_{1} \text { and } \mathrm{FEF}_{25 / 75} \text { in all smoking } \\
\text { categories }\end{array}$ \\
\hline 23 & $\begin{array}{l}\text { Canadian asbestos miners } \\
\mathrm{n}=983\end{array}$ & $\begin{array}{l}\text { Many exposure-time } \\
\text { variables }\end{array}$ & $\begin{array}{l}\text { Airflow limitation associated with exposure, weighted for } \\
\text { residence time in the lung } \\
\text { An increased effect suggested for earlier exposure }\end{array}$ \\
\hline 24 & $\begin{array}{l}\text { US boilermakers } \\
\mathrm{n}=534\end{array}$ & Duration of work in trade & $\begin{array}{l}\text { Significantly decreased } \mathrm{FEV}_{1} / \mathrm{FVC} \% \text { associated with more than } \\
20 \text { years in trade, but not with job status (welder, etc) }\end{array}$ \\
\hline 25 & $\begin{array}{l}\text { Canadian asbestos insulators } \\
\text { over age } 50 \\
n=88\end{array}$ & $\begin{array}{l}\text { Insulators vs } \\
\text { reference population }\end{array}$ & $\begin{array}{l}35 \% \text { had airflow obstruction, associated with diffuse pleural } \\
\text { abnormality and history of work in pulp mills }\end{array}$ \\
\hline 26 & $\begin{array}{l}\text { US asbestos union members } \\
\text { with normal } x \text {-rays } \\
n=113\end{array}$ & Duration of work in trade & $\begin{array}{l}\text { Significant decrease in } \mathrm{FEV}_{1} / \mathrm{FVC} \% \text { and } \mathrm{FEF}_{25 / 75} \text { with more than } \\
20 \text { years in trade } \\
\text { Effect of more than } 20 \text { years similar to effect of smoking } \\
\text { Effects are additive }\end{array}$ \\
\hline 27 & $\begin{array}{l}\text { Italian asbestos cement } \\
\text { factory workers } \\
n=65\end{array}$ & $\begin{array}{l}\text { Duration of work in trade; } \\
\text { asbestos workers vs } \\
\text { controls }\end{array}$ & $\begin{array}{l}\text { Significantly greater } \mathrm{FEV}_{1} \text { and FVC decline in asbestors workers } \\
\text { FVC decline increased with more than } 15 \text { years in trade }\end{array}$ \\
\hline 28 & $\begin{array}{l}\text { US Wollastonite miners } \\
n=108\end{array}$ & $\begin{array}{l}\text { Cumulative exposure; miners } \\
\text { vs controls }\end{array}$ & $\begin{array}{l}\text { Significant dose-response of dust with } \mathrm{FEV}_{1} / \mathrm{FVC} \\
\text { More pronounced in nonsmokers }\end{array}$ \\
\hline
\end{tabular}

FEF $_{25 / 75}$ Maximal midexpiratory flow rate; FEV 1 Forced expiratory volume in 1 s; FVC Forced vital capacity

pronounced among nonsmokers than among smokers. A case-control study of South African gold miners (16) found that 20 years of working in a high dust exposure job was associated with a 13-fold increase in emphysema risk, independent of the effects of smoking. Studies of autopsied lungs (17-20) supported the results of the above epidemiological studies that exposure to mining dusts (coal or silica) were found to increase the risk of developing emphysema.

Airflow obstruction has also been demonstrated in association with asbestos exposure (Table 1) (21-27), and doseresponse relationships are apparent $(21,24,26)$. Airflow obstruction tends to be associated with both pleural and parenchymal radiographic abnormalities in asbestos exposed subjects. Wollastonite miners (28) also showed a dose-response relationship of cumulative exposure with decreased lung function; the relationship was more pronounced in nonsmokers.

\section{ORGANIC DUSTS}

Many organic dusts have been shown to give rise to occupational asthma. It has also been demonstrated that the majority of patients with occupational asthma do not recover several years after removal from exposure and some patients develop persistent chronic airflow limitation requiring medications for treatment (29).

Cotton dust: Whether cotton dust exposure has chronic effects on the lungs capable of disabling those affected has been the subject of debate for many years and is still not resolved. Neither pathology studies $(30,31)$ nor mortality studi- es (32) concerning cotton dust showed convincing evidence of a relationship between cotton dust exposure and emphysema.

Cross-sectional studies concerning the health effects of cotton dust exposure (33-35) show a dose-response relationship between exposure and the prevalence of chronic bronchitis and/or lung function level. The results of the 
TABLE 2

Grain dust exposure: Relationship between exposure and airflow limitation in studies controlling for the effects of smoking

\begin{tabular}{|c|c|c|c|}
\hline Reference & Population & Exposure measure & Relationship between exposure and outcome \\
\hline 44 & $\begin{array}{l}\text { New York grain workers } \\
n=55\end{array}$ & $\begin{array}{l}\text { Grain workers vs } \\
\text { bakers }\end{array}$ & $\begin{array}{l}\text { Grain workers had significantly lower lung function than bakers } \\
\text { Effect of smoking similar to effect of exposure } \\
\text { No smoking-exposure interaction }\end{array}$ \\
\hline 45 & $\begin{array}{l}\text { Thunder Bay grain workers } \\
n=441\end{array}$ & $\begin{array}{l}\text { Grain workers vs } \\
\text { civic controls }\end{array}$ & $\begin{array}{l}\text { Grain workers had significantly lower lung function than civic workers } \\
\text { Effect of smoking greater than effect of dust exposure } \\
\text { No smoking-exposure interaction }\end{array}$ \\
\hline 46 & $\begin{array}{l}\text { St Lawrence grain }(n=103) \\
\text { and port workers }(n=39)\end{array}$ & $\begin{array}{l}\text { Grain vs } \\
\text { port workers }\end{array}$ & $\begin{array}{l}\text { Grain workers had significantly lower lung function than port workers } \\
\text { Effect of exposure greater than effect of smoking } \\
\text { No smoking-exposure interaction }\end{array}$ \\
\hline 47 & $\begin{array}{l}\text { Vancouver grain workers } \\
\qquad n=610\end{array}$ & $\begin{array}{l}\text { Grain workers vs } \\
\text { civic controls }\end{array}$ & $\begin{array}{l}\text { Grain workers had significantly lower lung function than civic workers } \\
\text { Effect of exposure similar to that of smoking } \\
\text { No smoking-exposure interaction }\end{array}$ \\
\hline 48 & $\begin{array}{l}\text { Saskatchewan grain workers } \\
n=390\end{array}$ & $\begin{array}{l}\text { Grain workers vs } \\
\text { civic controls }\end{array}$ & $\begin{array}{l}\text { Grain workers had significantly lower lung function than civic workers } \\
\text { Effect of exposure similar to effect of smoking } \\
\text { Smoking and exposure effects additive }\end{array}$ \\
\hline 49 & $\begin{array}{l}\text { Alberta grain workers } \\
n=63\end{array}$ & $\begin{array}{l}\text { Grain workers vs } \\
\text { civic controls }\end{array}$ & $\begin{array}{l}\text { Grain workers had significantly lower lung function than civic workers } \\
\text { Effect of smoking greater than effect of exposure } \\
\text { No smoking-exposure interaction }\end{array}$ \\
\hline
\end{tabular}

longitudinal studies (36-40) are not as consistent. For those studies with dust measurements, a dose-response relationship was found between the annual decline in $\mathrm{FEV}_{1}$ and the degree of dust exposure. A cross-sectional study of active and retired cotton textile workers in the United States (41) showed a high prevalence of respiratory symptoms among these exposed workers in comparison with controls. A longitudinal study of this cohort (42) showed greater declines in $\mathrm{FEV}_{1}$ than for controls, even within each smoking group. The average $\mathrm{FEV}_{1}$ declines were $42 \mathrm{~mL} / \mathrm{year}$ and 25 $\mathrm{mL} /$ year, respectively. It was concluded that chronic lung disease was not only more prevalent among cotton workers, regardless of smoking group, but that the disease may progress after exposure to cotton dust had ended.

Grain dust: The impact of grain dust on the lungs has been reviewed recently in detail (43). Several syndromes have been reported arising from exposure to grain dust: grain dust asthma, asthma-like syndrome, hypersensitivity pneumonitis, and skin and mucous membrane irritation. Although the acute airway diseases to grain dust have been recognized, it is not as clear whether chronic exposure to grain dust leads to chronic airflow limitation with disability. The majority of the cross-sectional studies showed increases in chronic respiratory symptoms and lower lung function in grain workers compared with the unexposed controls (Table 2) (44-49).

The first five cross-sectional surveys of grain elevator workers in the Port of Vancouver showed consistently that, within each smoking group, grain workers have lower lung function than a group of controls studied in the same manner over the years (50). An exposure-response relationship was also shown, which persisted across all smoking categories (51). Longitudinal analysis of workers who took part in the first three years showed that grain workers had a more rapid decline in lung function than the control group; the disparity in $\mathrm{FEV}_{1}$ decline was greater among nonsmokers $(-31$ $\mathrm{mL} /$ year versus $+4 \mathrm{~mL} /$ year) than among smokers $(-37$
$\mathrm{mL} /$ year versus $-31 \mathrm{~mL} /$ year) (52). After 12 years of followup, longitudinal changes in lung function were comparable between the two groups, but selection effects were apparent in that dropouts had more symptoms and lower lung function in the initial survey (50). Retired grain workers had significantly lower lung function compared with the controls and a significantly higher proportion with $\mathrm{FEV}_{1}$ below $80 \%$ predicted after adjustment for smoking (53). An exposure-response relationship was also found in this group of retirees. There was no improvement in the lung function of the grain workers after their retirement to indicate that the effect of grain dust exposure is reversible.

Agricultural dust: In agriculture, organic dust particles are formed from microbial cells and spores, abrasion between fragments of feed and bedding, from milling, grinding or chopping feeds, and include animal dander, urine and feces (54).

A review of 14 cross-sectional studies of swine confinement workers by Donham (55) in 1990 found cough and phlegm to be the most common symptoms, ranging from 12 to $55 \%$ across the studies.

When unexposed control groups were used, differences in the prevalence of respiratory symptoms, chronic bronchitis and lung function were usually found. For example, dairy farmers were matched to nonfarmer controls by sex, age, height and smoking habits (56). The farmers had a higher prevalence of chronic bronchitis (12\% versus $6 \%)$ and lower lung function.

Differences in respiratory outcomes were also found, dependent on the type of farming. Swine confinement farmers were found to have more symptoms of chronic bronchitis (28\% versus $17 \%$ ) and lower lung function than grain farmers, even after adjustment for smoking (57). A different study of Canadian farmers found dairy and pig farmers had lower lung function than grain farmers, who were no different from nonfarming controls (58). Exposure-response relationships have been suggested in that the number of hours of work per 
TABLE 3

Mixed mineral dust and fume exposure: Relationship between exposure and airflow limitation in studies controlling for the effects of smoking

\begin{tabular}{|c|c|c|c|}
\hline Reference & Population & Exposure measure & Relationship between outcome and exposure \\
\hline 65 & $\begin{array}{l}\text { Canadian miners and } \\
\text { smelter workers } \\
n=241\end{array}$ & $\begin{array}{l}\text { Miners, smelter } \\
\text { workers vs } \\
\text { population controls }\end{array}$ & $\begin{array}{l}\text { Significant reduction in airflow rates in exposed smokers, most } \\
\text { prominent among smelter workers } \\
\text { Decreased airflow rates in association with increased duration of } \\
\text { employment (miners only) } \\
\text { Positive smoking-exposure interaction }\end{array}$ \\
\hline 66 & $\begin{array}{l}\text { British engineering } \\
\text { factory welders } \\
n=258\end{array}$ & Welders vs controls & $\begin{array}{l}\text { No difference in airflow rates between welders and controls for the } \\
\text { total group } \\
\text { A subset of smoking welders had small reductions in flow rates at } \\
\text { low lung volumes }\end{array}$ \\
\hline 67 & $\begin{array}{l}\text { British shipyard welders and } \\
\text { caulkers/burners } \\
n=607\end{array}$ & $\begin{array}{l}\text { Average total welding } \\
\text { fume exposure }\end{array}$ & $\begin{array}{l}\text { Significantly reduced airflow rates associated with average exposure } \\
\text { in smokers and ex-smokers } \\
\text { Positive interaction between welding exposure and age effects on } \\
\text { airflow }\end{array}$ \\
\hline 68 & $\begin{array}{l}\text { British shipyard welders and } \\
\text { caulkers/burners } \\
n=488\end{array}$ & $\begin{array}{l}\text { Welders, } \\
\text { caulkers/burners vs } \\
\text { other trade }\end{array}$ & $\begin{array}{l}\text { Annual decline in FEV } 12 \text { times greater in welders or caulker/burners } \\
\text { than in other trades } \\
\text { Significant positive interaction between smoking and exposure }\end{array}$ \\
\hline 69,70 & $\begin{array}{l}\text { US rubber manufacturing } \\
\text { workers (curing, } \mathrm{n}=121 \text {; } \\
\text { production, } \mathrm{n}=65)\end{array}$ & $\begin{array}{l}\text { Job type vs controls, } \\
\text { duration of exposure }\end{array}$ & $\begin{array}{l}\text { Significantly decreased } \mathrm{FEV}_{1} / \mathrm{FVC} \text { associated with production work } \\
\text { Significantly decreased } \mathrm{FEV}_{1} \text { associated with increasing years of } \\
\text { exposure to dust } \\
\text { Steeper } \mathrm{FEV} \mathrm{V}_{1} \text { slope associated with increased years of employment } \\
\text { in curing department }\end{array}$ \\
\hline
\end{tabular}

FEV 1 Forced expiratory volume in 1 s; FVC Forced vital capacity

day in confinement buildings was negatively correlated to FVC (57) in a Canadian study, while a $12 \mathrm{~mL}$ reduction in $\mathrm{FEV}_{1}$ was associated with each year of hog farming in a Danish study (59).

Wood dust: Exposure to many of the exotic woods has been shown to give rise to occupational asthma. Exposure to wood dust has also been found to give rise to chronic respiratory symptoms and lower lung function in surveys of woodworkers compared with unexposed controls.

A greater prevalence of chronic cough and phlegm and lower lung function was found among Canadian sawmill workers exposed to Western red cedar as opposed to other types of wood dust such as hemlock and fir (60). Compared with office workers with no exposure to wood dust, cedar sawmill workers had higher odds ratios of cough and phlegm and lower lung function after adjusting for differences in smoking habits (61). The decrease in lung function was not due to the increased prevalence of asthma in cedar mills since exclusion of these subjects from analysis failed to influence the results. The annual decline in lung function in cedar workers was also significantly greater than in the control group (62) (-29 mL/year versus $2 \mathrm{~mL} /$ year in nonsmokers), suggesting that workers exposed to Western red cedar are at risk for developing chronic airflow obstruction.

A study was conducted on workers exposed to hardwood dust (mostly maple) and varying levels of soft wood dust (pine) (63) who did not have exposure to other industrial agents such as adhesives and finishing agents. Workers in the high exposure category to both hard wood and pine dust had two to four times the prevalence of low expiratory flow rates compared with those exposed to lower levels of dust, irrespective of their smoking habits. Cabinet workers exposed to different types of wood (64) reported more cough, phlegm and wheeze but their mean lung function was not significantly different from that of the controls.

\section{MIXED DUST, FUMES AND GAS EXPOSURE}

Studies of chronic airflow obstruction in groups exposed to mixtures of dust, fumes and gases have often found a significant excess of chronic airflow limitation in these workers (65-70), although there are exceptions (66) (Table 3). Such exposures are found in mineral processing (steelmaking, foundries, smelters) and in a wide variety of other industries ranging from rubber manufacturing to firefighting. Temperature extremes are also generally found in these work environments.

Mixed or nonspecific exposures have also been examined in several population-based cross-sectional (71-74) and longitudinal studies (75-76) (Table 4). In these studies, exposure measurements are seldom available; rather, exposure is assigned based on responses to questions regarding general work exposures, job and industry titles, and employment duration. As such, it is important to bear in mind that the inevitable misclassification of exposure will result in a diminution of effect. The populations studied have included rural and urban locations from the United States, Norway, France, China and Poland. The studies generally found increased prevalence rates for cough and phlegm and measures of airflow obstruction for those with mixed dust exposures, after controlling for the effects of smoking, and dose-response relationships were often seen (77). The effect of temperature extremes and gas or fume exposure in addition to dust appears to be additive in most studies. In a longitudinal study of Paris area workers, Kauffmann (75) found that the rate of longitudinal decline in $\mathrm{FEV}_{1}$ in men with no change in smoking habit increased with exposure combinations as follows: 
TABLE 4

Population based studies: Relationship between exposure and airflow limitation in studies controlling for the effects of smoking

\begin{tabular}{|c|c|c|c|}
\hline Reference & Population & Exposure measure & Relationship between outcome and exposure \\
\hline 71 & $\begin{array}{l}\text { Sample of residents from } \\
6 \text { US cities } \\
n=8515\end{array}$ & $\begin{array}{l}\text { Questionnaire: job with } \\
\text { potential exposure to } \\
\text { dust, gas/fumes }\end{array}$ & $\begin{array}{l}\text { Increased relative odds for airflow limitation associated with dust } \\
\text { alone }(O R=1.7) \text { and with dust and fumes combined }(O R=1.6) \\
\text { No smoking-exposure interaction }\end{array}$ \\
\hline 72 & $\begin{array}{l}\text { Stratified sample of residents } \\
\text { of Hordaland county, Norway } \\
n=714\end{array}$ & $\begin{array}{l}\text { Questionnaire: job with } \\
\text { potential 'airborne } \\
\text { exposure' ( } 3 \text { levels) }\end{array}$ & $\begin{array}{l}\text { Increased relative odds for obstruction associated with high level } \\
\text { exposure jobs }(\mathrm{OR}=3.6) \\
\text { Effect of exposure more pronounced in older workers } \\
\text { No smoking-exposure interaction }\end{array}$ \\
\hline 73 & $\begin{array}{l}\text { Residents from } 24 \text { areas of } 7 \\
\text { French cities (excluding } \\
\text { households headed by a } \\
\text { 'manual worker') } \\
n=12,182\end{array}$ & $\begin{array}{l}\text { Questionnaire: exposed } \\
\text { to dust, gases or } \\
\text { chemical fumes in any } \\
\text { job }\end{array}$ & $\begin{array}{l}\mathrm{FEV}_{1} / \mathrm{FVC} \text { significantly reduced in exposed group } \\
\text { Effect of exposure most pronounced in older subjects. Exposure } \\
\text { effect about half the smoking effect }\end{array}$ \\
\hline 74 & $\begin{array}{l}\text { Sample of residents of Beijing } \\
\text { not using coal for heat } \\
n=1094\end{array}$ & $\begin{array}{l}\text { Questionnaire: } \\
\text { cumulative exposure } \\
\text { (3 levels) to dust or to } \\
\text { gas/fumes }\end{array}$ & $\begin{array}{l}\text { Significant reduction in } \mathrm{FEV}_{1} \text { and } \mathrm{FEF}_{25-75} \text { associated with exposure } \\
\text { to dust (compared to no exposure) } \\
\text { Significant dose-response trend for } \mathrm{FEV}_{1} \text { related to increasing } \\
\text { gas/fumes exposure among exposed subjects } \\
\text { Signicant interaction between smoking and dust exposure on } \\
\mathrm{FEV}_{1} / \mathrm{FVC}\end{array}$ \\
\hline 75 & $\begin{array}{l}\text { Workers from } 11 \text { Paris } \\
\text { factories } \\
n=556\end{array}$ & $\begin{array}{l}\text { Technical survey: } \\
\text { exposure to dust ( } 5 \\
\text { levels), gases ( } 2 \\
\text { levels), heat ( } 3 \text { levels) }\end{array}$ & $\begin{array}{l}\text { More rapid decline in } \mathrm{FEV}_{1} \text { associated with dust alone, heat alone, } \\
\text { and gas in combination with dust and/or heat } \\
\text { Steeper slopes among unskilled workers } \\
\text { Workers in } 30-39 \text { age group had higher initial } \mathrm{FEV}_{1} \text { but equally } \\
\text { steep slopes as for older workers }\end{array}$ \\
\hline 76 & $\begin{array}{l}\text { Random sample of residents } \\
\text { of Cracow } \\
n=1679\end{array}$ & $\begin{array}{l}\text { Questionnaire: history of } \\
\text { exposure to dusts, } \\
\text { variable temperature, } \\
\text { chemicals }\end{array}$ & $\begin{array}{l}\text { More rapid decline in } \mathrm{FEV}_{1} \text { associated with prolonged exposure to } \\
\text { variable temperature, and acute exposure to irritating gases } \\
\text { Exposure regression coefficients larger than that for smoking; no } \\
\text { smoking-exposure interaction }\end{array}$ \\
\hline
\end{tabular}

FEF 25/75 Maximal midexpiratory flow rate; FEV 1 Forced expiratory volume in $1 \mathrm{~s}$; FVC Forced vital capacity; OR Odds ratio

no exposure or exposure only to slight dust or only to gases (44 mL/year); exposure to noticeable dust (50 mL/year); exposure to heat (59 $\mathrm{mL} /$ year); exposure to noticeable dust and heat $(56 \mathrm{~mL} /$ year); and exposure to noticeable dust, high level of gases, and heat ( $67 \mathrm{~mL} /$ year). Similar combinations of the effect of variable temperature and chemicals were also seen in a 13-year follow-up study of Cracow residents $(76,77)$. A threefold increase in the risk for emphysema has also been shown to be related to exposure in a populationbased case-control study (78) in Norway.

\section{CONCLUSIONS}

Both epidemiological and autopsy findings support the suggestion that exposure to inorganic dust is causally associated with chronic airflow obstruction because they satisfy most of Hill's criteria for causality. In particular, the demonstration of an exposure-response relationship according to the degree of dust exposure provides a strong basis for concluding that there is a causal relationship, particularly where cigarette smoking has been taken into account in the design or analysis of the studies.

The results of studies of organic dusts are not nearly as uniform. Studies of cotton and grain dust tend to show crosssectional differences in lung function between exposed and unexposed groups; the findings for longitudinal studies were less consistent. The studies of retired grain workers provide further evidence of the deleterious effects of exposure to grain dust, which confirms the previous findings of chronic airflow limitation. Farmers tend to show increased respiratory symptoms and lower lung function, compatible with chronic airflow limitation. The degree of limitation appears to be dependent on the type of farming, such as animal confinement, but cumulative exposure analyses to determine dose-response relationships have not yet been investigated. Exposures to different types of wood dust were found to be associated with chronic respiratory symptoms and some impairment of lung function; however, further studies are necessary on woodworkers with specific exposure to individual species of wood in order to delineate the respiratory effects of exposure.

There is sufficient evidence that occupational exposures to dust can result in chronic airflow limitation. In most instances no statistical interaction was shown between smoking and dust exposure, ie, they were separate additive effects. In many studies, the effects of dust exposure were found to be more pronounced than what was found for smoking. Not all dust exposures are implicated, nor all levels of exposure, nor all circumstances under which an exposure might occur. However, the evidence is strong enough, particularly in relation to inorganic dust and grain dust exposure, that an occupational history should be considered as integral a part of the investigation of a patient with chronic airflow limitation, as is the smoking history. Further study of the chronic respiratory effects of organic dust exposure is warranted, especially where quantitative estimates of both dust exposures and smoking are considered. 


\section{REFERENCES}

1. Sadoul P. Pneumoconiosis in Europe yesterday, today and tomorrow. Env J Respir Dis 1983;64(Suppl 126):177-82.

2. Bates DV. Respiratory Function in Disease, 3rd edn. Philadelphia: WB Saunders Co, 1989.

3. Louis TA, Robins J, Dockery DW, Spiro A II, Ware JH. Explaining discrepancies between longitudinal and cross-sectional models. J Chron Dis 1986;39:831-9.

4. Kennedy SM. Mixed dusts, fumes and gases. Work-related chronic obstructive pulmonary disease. In: Schenker M, Balmes J, Harber P, eds. Occupational and Environmental Respiratory Diseases. New York: Mosby-Yearbook, 1995.

5. Hill AB. The environment and disease: association or causation. Proc R Soc Med 1965;58:295-300.

6. Higgins ITT. The epidemiology of chronic respiratory disease. Prev Med 1973;2:14-33.

7. Becklake MR. Chronic airflow limitation: its relationship to work in dusty occupation. Chest 1985;88:608-17.

8. Love RG, Miller BG. Longitudinal study of lung function in coal-miners. Thorax 1982;37:193-7.

9. Fairman RP, O’Brien RJ, Swecker S, Amandus HI, Shoub EP. Respiratory status of surface coal miners in the United States. Arch Environ Health 1977;32:211-5.

10. Marine WM, Gurr D, Jacobsen M. Clinically important respiratory effects of dust exposure and smoking in British coal miners. Am Rev Respir Dis 1988;137:106-12.

11. Attfield MD. Longitudinal decline in $\mathrm{FEV}_{1}$ in United States coalminers. Thorax 1985;40:132-7.

12. Seixas NS, Robins TG, Attfield MD, Moulton LH. Longitudinal and cross-sectional analyses of coal mine dust and pulmonary function in new miners. Br J Ind Med 1993;50:929-37.

13. Oxman AD, Muir DCF, Shannon HS, Stock SR, Hnizdo E, Lange HJ. Occupational dust exposure and chronic obstructive pulmonary disease. Am Rev Respir Dis 1993;148:38-48.

14. Hnizdo E, Baskind E, Sluis-Cremer GK. Combined effect of silica dust exposure and tobacco smoking on the prevalence of respiratory impairments among gold miners. Scand J Work Environ Health 1990;16:411-22.

15. Holman CDJ, Psaila-Savona P, Roberts M, McNulty JC. Determinants of chronic bronchitis and lung dysfunction in Western Australian gold miners. Br J Ind Med 1987;44:810-8.

16. Becklake MR, Irwig L, Kielkowski D, Webster I, de Beer M, Landau $\mathrm{S}$. The predictors of emphysema in South African gold miners. Am Rev Respir Dis 1987; 135:1234-41.

17. Leigh J, Outhred KG, McKenzie HI, Wiles AN. Multiple regression analysis of quantified aetiological, clinical and postmortem pathological variables related to respiratory disease in coal workers. Ann Occup Hyg 1982;26:383-400.

18. Becklake MR, Irwig L, Kielkowski D, Webster I, de Beer M, Landau $\mathrm{S}$. The predictors of emphysema in South African gold miners. Am Rev Respir Dis 1987;135:1234-41.

19. Cockroft A, Seal RM E, Wagner JC, Lyons JP, Ryder R, Andersson N. Postmortem study of emphysema in coalworkers and non-coal workers. Lancet 1982;ii:600-3.

20. Ruckley VA, Gauld SJ, Chapman JS, et al. Emphysema and dust exposure in a group of coal workers. Am Rev Respir Dis 1984;129:528-32

21. Begin R, Boileau R, Peloquin S. Asbestos exposure, cigarette smoking and airflow limitation in long-term Canadian chrysotile miners and millers. Am J Ind Med 1987;11:55-66.

22. Kilburn KH, Warshaw RH, Einstein K, Bernstein J. Airway disease in non-smoking asbestos workers. Arch Environ Health 1985;40:293-5.

23. Copes R, Thomas D, Becklake MR. Temporal patterns of exposure and non-malignant pulmonary abnormality in Quebec chrysotile workers. Arch Environ Health 1985;40:80-7.

24. Demers RY, Neale AV, Robins T, Herman SC. Asbestos-related disease in boilermakers. Am J Ind Med 1990;17:327-39.

25. Kennedy SM, Vedal S, Muller N, Kassam A, Chan-Yeung M. Lung function and chest radiograph abnormalities among construction insulators. Am J Ind Med 1991;20:673-84.

26. Hall SK, Cissik JH. Effects of cigarette smoking on pulmonary function in asymptomatic asbestos workers with normal chest radiographs. Am Ind Hyg Assoc J 1982;43:381-6.

27. Siracusa A, Cicioni C, Volpi R, et al. Lung function among asbestos cement factory workers: cross-sectional and longitudinal study. Am J Ind Med 1984;5:315-25.
28. Hanke W, Sepulveda M-J, Watson A, Jankovic J. Respiratory morbidity in wollastonite workers. Br J Ind Med 1984;41:474-9.

29. Chan-Yeung M. Occupational asthma. Chest 1990;98(Suppl):1485-615.

30. Pratt PC, Vollmer RT, Miller JA. Epidemiology of pulmonary lesions in non-textile workers - a retrospective autopsy analysis. Arch Environ Health 1980;35:133-8.

31. Moran TJ. Emphysema and other chronic lung disease in textile workers - an 18 year autopsy study. Arch Environ Health 1983;38:267-76.

32. Merchant JA, Ortmeyer C. Mortality of employees of two cotton mills in North Carolina. Chest 1981;79(Suppl 4):6s-11s.

33. Lu P-L, Christiani D, Ye T-T, et al. The study of byssinosis in China: a comprehensive report. Am J Ind Med 1987;12:743-53.

34. Fox AJ, Tombleson JBL, Watt A, Wilkie AG. A survey of respiratory disease in cotton operatives. Part I. Symptoms and ventilatory results. Br J Ind Med 1973;30:42-7.

35. Woldeyohannes M, Bergevin Y, Mgeni A, Theriault G. Respiratory problems among cotton textile mill workers in Ethiopia. Br J Ind Med 1991;48:110-5.

36. Berry G, McKerrow CB, Molyneux MKB, Rossiter CE, Tombleson JBL. A study of the acute and chronic changes in ventilatory capacity of workers in Lancashire cotton mills. Br J Ind Med 1973;30:25-36.

37. Kamat SR, Kamat GR, Salpekar VY, Lobo E. Distiguishing byssinosis from chronic obstructive pulmonary disease. Results of a prospective five-year study of cotton mill workers in India. Am Rev Respir Dis 1981;124:31-40.

38. Larson RK, Barman ML. A longitudinal study of pulmonary function in cotton gin workers in the San Joaquin Valley. Chest 1989;96:819-23.

39. Zuskin E, Ivankovic D, Schachter EN, Witek TJ. A ten-year follow-up study of cotton textile workers. Am Rev Respir Dis 1991;143:301-5.

40. Glindmeyer HW, Lefante JJ, Jones RN, Rando RJ, Abdel Kader HM, Weill H. Exposure-related declines in the lung function of cotton textile workers. Relationship to current workplace standards. Am Rev Respir Dis $1991 ; 144: 675-83$.

41. Bouhuys A, Schoenberg JB, Beck GJ, Schilling RSF. Epidemiology of chronic lung disease in a cotton mill community. Lung 1977; $154: 167-86$.

42. Beck GJ, Schachter EN, Maunder LR, Schilling RSF. A prospective study of chronic lung disease in cotton textile workers. Ann Intern Med 1982;97:645-51.

43. Chan-Yeung M, Enarson DA, Kennedy S. The impact of grain dust on health. Am Rev Respir Dis 1992;145:476-87.

44. Kleinfeld M. A comparative clinical and pulmonary function study of grain handlers and bakers. Ann NY Acad Sci 1974;221:86-96.

45. Broder I, Mintz S, Hutcheon M, et al. Comparison of respiratory variables in grain elevator workers and civic outside workers of Thunder Bay, Canada. Am Rev Respir Dis 1979;119:193-203.

46. Becklake MR, Jodoin G, Lefort L. A respiratory health study of grainhandlers in St. Lawrence River ports. In: Dosman J, Cotton D, eds. Occupational Pulmonary Diseases. New York: Academic Press, Inc, 1980:239-55.

47. Chan-Yeung M, Schulzer M, MacLean L, Dorken E, Grzybowski S Epidemiologic health survey of grain elevator workers in British Columbia. Am Rev Respir Dis 1980;121:329-38.

48. Cotton DJ, Graham BL, Li KY, Froh F, Barnett GD, Dosman JA. Effects of grain dust exposure and smoking on respiratory symptoms and lung function. J Occup Med 1983;25:131-41.

49. Herbert FA, Woytowich V, Schram E, Baldwin D. Respiratory profiles of grain handlers and sedentary workers. Can Med Assoc J 1981;125:46-50.

50. Chan-Yeung M, Dimich-Ward H, Enarson DA, Kennedy SM. Five cross-sectional studies of grain elevator workers. Am J Epidemiol 1992;136:1269-79.

51. Huy T, De Schipper K, Chan-Yeung M, Kennedy SM. Grain dust and lung function. Dose-response relationships. Am Rev Respir Dis 1991;144:1314-21.

52. Schulzer M, Enarson DA, Chan-Yeung M. Analyzing cross-sectional and longitudinal lung function measurements; the effect of age. Can J Statistics 1985;13:7-15.

53. Kennedy SM, Dimich-Ward H, Desjardins A, Kassam A, Vedal S, Chan-Yeung M. Respiratory health among retired grain elevator workers. Am J Respir Crit Care Med 1994;150:59-65.

54. Watson R. Prevention of dust exposure. Am J Ind Med 1986;10:229-43.

55. Donham K. Health effects from work in swine confinement buildings. Am J Ind Med 1990;17:17-25.

56. Dalphin J, Bildstein F, Pernet D, Dubiez A, Depierre A. Prevalence of 
chronic bronchitis and respiratory function in a group of dairy farmers in the French Doubs province. Chest 1989;95:1244-7.

57. Zejda J, Gomez S, Hurst T, et al. Respiratory health of swine producers working in livestock confinement buildings. Third International Symposium, Issues in Health, Safety and Agriculture, Saskatoon, May 1992.

58. Manfreda J, Chang M, Warren CPW. Chronic respiratory disorders related to farming and exposure to grain dust in a rural community. Am J Ind Med 1988;15:7-19.

59. Iversen M, Pedersen B. Relationship between respiratory symptoms, type of farming, and lung function disorders in farmers. Thorax 1990;45:919-23.

60. Chan-Yeung M, Ashley MJ, Corey P, Willson G, Dorken E, Grzybowski S. A respiratory survey of cedar mill workers. I. Prevalence of symptoms and pulmonary function abnormalities. J Occup Med 1978;20:323-7.

61. Chan-Yeung M, Vedal S, Kus J, MacLean L, Enarson D, Tse KS. Symptoms, pulmonary function, and bronchial hyperreactivity in western red cedar workers compared with those in office workers. Am Rev Respir Dis 1984;130:1038-41.

62. Chan-Yeung M, Vedal S, Kennedy S. A longitudinal study of red cedar sawmill workers. Am Rev Respir Dis 1990;141:A80.

63. Whitehead LW, Ashikaga T, Vacek P. Pulmonary function status of workers exposed to hardwood or pine dust. Am Ind Hyg Assoc J 1981;42:178-86.

64. Holness DL, Sass-Kortsak AM, Pilger CW, Nethercott JR. Respiratory function and exposure effect relationships in wood dust-exposed and control workers. J Occup Med 1985;27:501-6.

65. Manfreda J, Sidwall G, Maini K, West P, Cherniack RM. Respiratory abnormalities in employees of the hard rock mining industry. Am Rev Respir Dis 1982;126:629-39.

66. Hayden SP, Pincock AC, Hayden J, Tyler LE, Cross KW, Bishop JM. Respiratory symptoms and pulmonary function of welders in the engineering industry. Thorax 1984;39:442-7.

67. Cotes JE, Feinmann EL, Male VJ, Rennie FS, Wickham CAC
Respiratory symptoms and impairment in shipyard welders and caulker/burners. Br J Ind Med 1989;46:292-301.

68. Chinn DJ, Stevenson IC, Cotes JE. Longitudinal respiratory survey of shipyard workers: effects of trade and atopic status. Br J Ind Med 1990;47:83-90.

69. Fine LJ, Peters JM. Respiratory morbidity in rubber workers. I. Prevalence of respiratory symptoms and disease in curing workers. Arch Environ Health 1976;31:1-5.

70. Fine LJ, Peters JM. Respiratory morbidity in rubber workers. II. Pulmonary function in curing workers. Arch Environ Health 1976;31:6-10.

71. Korn RJ, Dockery DW, Speizer FE, Ware JH, Ferris BG. Occupational exposures and chronic respiratory symptoms. A population-based study. Am Rev Respir Dis 1987;136:298-304.

72. Bakke PS, Baste V, Hanoa R, Gulsvik A. Prevalence of obstructive lung disease in a general population: relation to occupational title and exposure to some airborne agents. Thorax 1991;46:863-70.

73. Krzyzanowski M, Kauffmann F. The relation of respiratory symptoms and ventilatory function to moderate occupational exposure in a general population. Int J Epidemiol 1988;17:397-406.

74. Xu X, Christiani D, Dockery C, Wang L. Exposure-response relationships between occupational exposures and chronic respiratory illness: a community-based study. Am Rev Respir Dis 1992;146:413-8.

75. Kauffman F, Drouet D, Lellouch J, Brille D. Occupational exposure and 12-year spirometric changes among Paris area workers. Br J Ind Med 1982;39:221-32.

76. Kzyzanowski M, Jedrychowski W, Wysocki M. Occupational exposures and changes in pulmonary function over 13 years among residents of Cracow. Br J Ind Med 1988;45:747-54.

77. Krzyzanowski M, Jedrychowski W. Occupational exposure and incidence of chronic respiratory symptoms among residents of Cracow followed for 13 years. Int Arch Occup Environ Health 1990;62:311-7.

78. Kjuus H, Istad H, Langard S. Emphysema and occupational exposure to industrial pollutants. Scand J Work Environ Health 1981;7:290-7. 


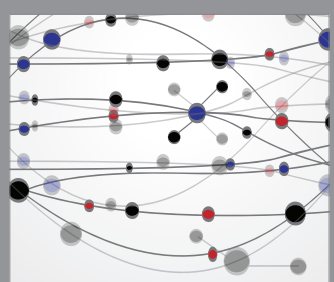

The Scientific World Journal
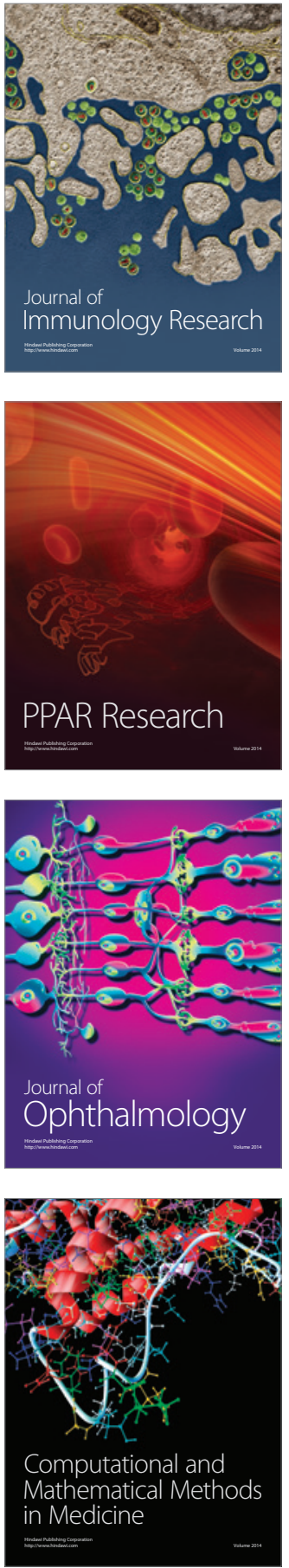

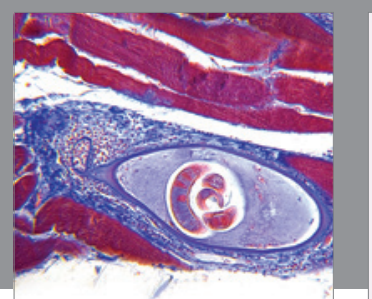

Gastroenterology Research and Practice

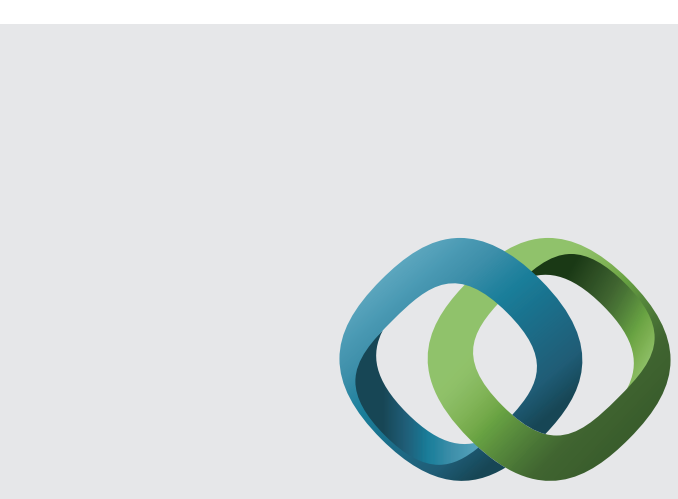

\section{Hindawi}

Submit your manuscripts at

http://www.hindawi.com
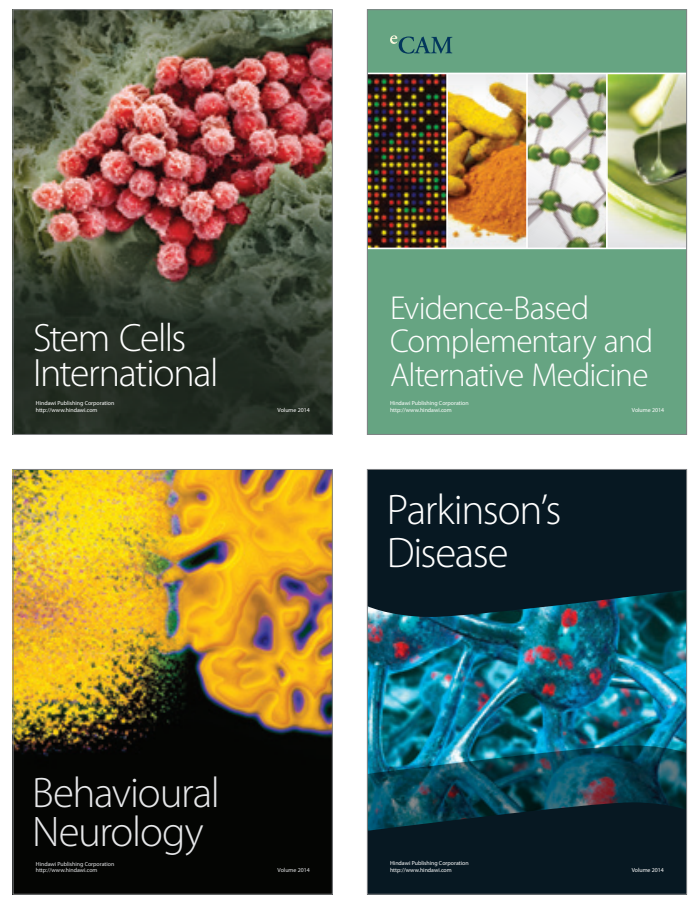
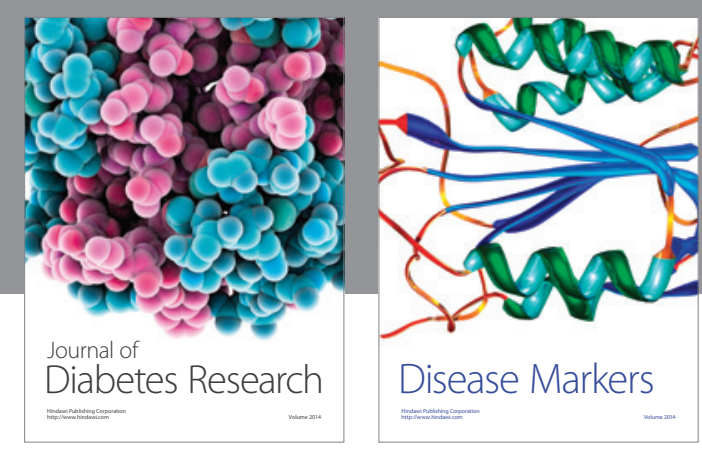

Disease Markers
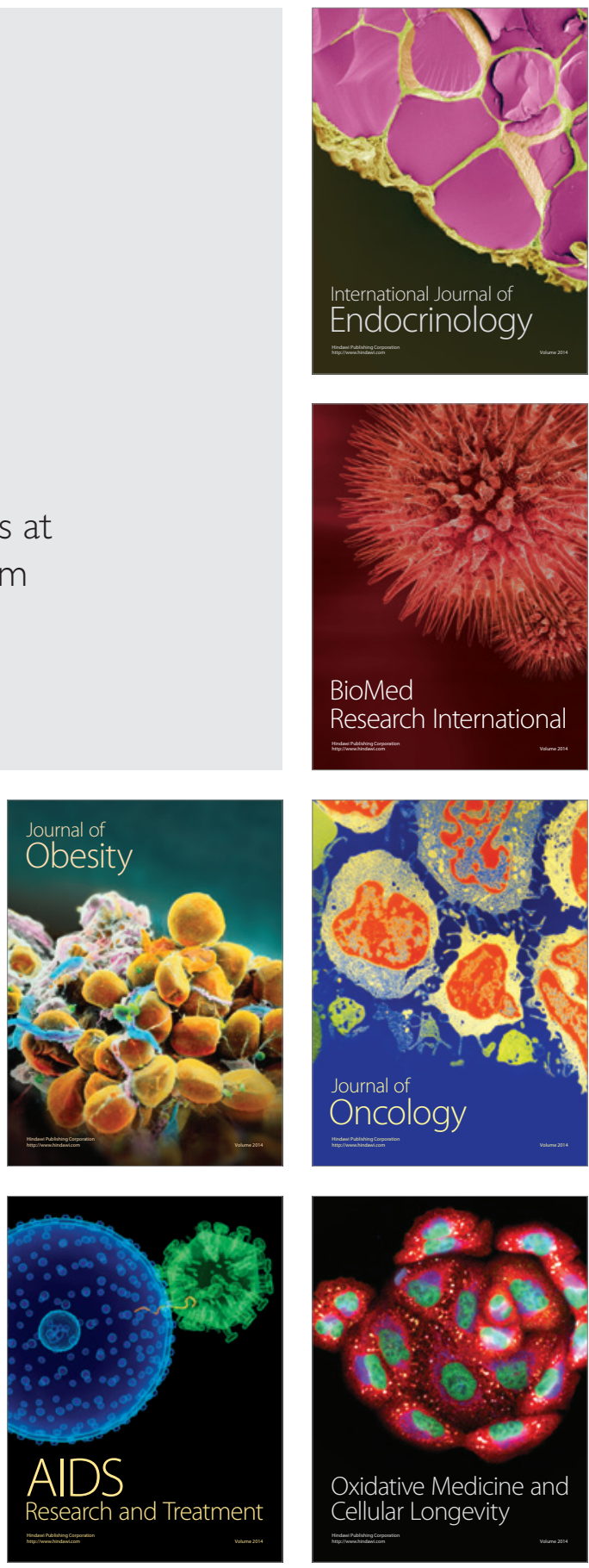